\title{
Papers
}

\section{Systematic review and meta-analysis of studies of the timing of tracheostomy in adult patients undergoing artificial ventilation}

\author{
John Griffiths, Vicki S Barber, Lesley Morgan, J Duncan Young
}

\begin{abstract}
Objective To compare outcomes in critically ill patients undergoing artificial ventilation who received a tracheostomy early or late in their treatment.

Data sources The Cochrane Central Register of Clinical Trials, Medline, Embase, CINAHL, the National Research Register, the NHS Trusts Clinical Trials Register, the Medical Research Council UK database, the NHS Research and Development Health Technology Assessment Programme, the British Heart Foundation database, citation review of relevant primary and review articles, and expert informants.

Study selection Randomised and quasi-randomised controlled studies that compared early tracheostomy with either late tracheostomy or prolonged endotracheal intubation. From 15950 articles screened, 12 were identified as "randomised or quasi-randomised" controlled trials, and five were included for data extraction.

Data extraction Five studies with 406 participants were analysed. Descriptive and outcome data were extracted. The main outcome measure was mortality in hospital. The incidence of hospital acquired pneumonia, length of stay in a critical care unit, and duration of artificial ventilation were also recorded. Random effects meta-analyses were performed.

Results Early tracheostomy did not significantly alter mortality (relative risk $0.79,95 \%$ confidence interval 0.45 to 1.39 ). The risk of pneumonia was also unaltered by the timing of tracheostomy $(0.90,0.66$ to 1.21$)$. Early tracheostomy significantly reduced duration of artificial ventilation (weighted mean difference -8.5 days, $95 \%$ confidence interval -15.3 to

-1.7 ) and length of stay in intensive care ( -15.3 days, -24.6 to $-6.1)$.

Conclusions In critically ill adult patients who require prolonged mechanical ventilation, performing a tracheostomy at an earlier stage than is currently practised may shorten the duration of artificial ventilation and length of stay in intensive care.
\end{abstract}

\section{Introduction}

Tracheostomy is among the most commonly conducted procedures in critically ill patients. It has many potential advantages over translaryngeal endotracheal intubation in the critical care setting, including reduced laryngeal ulceration and respiratory resistance; it is better tolerated by patients and improves their capacity to communicate; and it makes for easier nursing care. ${ }^{1-4}$ However, the procedure is not without risk. Complications resulting from the procedure include stomal infections, stomal haemorrhage, pneumomediastinum, pneumothorax, and occasionally death. ${ }^{5-8}$ Although the procedure used to create a tracheostomy does not influence outcome, as both surgical and percutaneous techniques carry comparable modest risks, the effect the timing of the procedure has on outcome is less clear. ${ }^{9-11}$

Evidence to guide practice has been limited. In 1989 the National Association of Medical Directors of Respiratory Care recommended that translaryngeal (endotracheal) intubation be used only for patients requiring less than 10 days of artificial ventilation and that a tracheostomy should be placed in patients who still require artificial ventilation 21 days after admission. ${ }^{12}$ Although these recommendations are based only on expert opinion, modern practice broadly seems to follow them. ${ }^{13}$ In 1997 Kane et al recommended early tracheostomy in patients with multiple injuries on the basis of a descriptive review of the relevant literature, ${ }^{14}$ but a systematic review (without metaanalysis) of randomised trials of tracheostomy timing published in 1998 by Maziak et al concluded that there was insufficient evidence to support the view that the timing of tracheostomy alters the duration of mechanical ventilation or extent of airway injury in critically ill patients. ${ }^{15}$ Since the review by Maziak et al we are aware that at least two more trials have been completed, both of which were methodologically more sound than their predecessors. ${ }^{16}{ }^{17}$ We decided to appraise critically and summarise all randomised clinical trials involving the timing of tracheostomy in adult patients in intensive care units.

\section{Methods}

We defined a randomised trial as one in which patients were assigned prospectively to either early tracheostomy or late (or no) tracheostomy by random allocation at time of enrolment. We defined early tracheostomy as a tracheostomy conducted up to seven days after admission to the intensive care unit, initiation of translaryngeal intubation, and mechanical ventilation. Late tracheostomy was any time thereafter.

We used several techniques to identify published and ongoing studies for this review. We searched Medline, CINAHL, Embase, the Cochrane Central Resister of Clinical Trials, the National Research Register, the NHS Trusts Clinical Trials Register, the Medical Research Council UK database, the NHS Research and Development Health Technology Assessment Programme, and the British Heart Foundation database in January, May, and November 2004. The search strategies for Medline were based on the terms recommended by the Cochrane Collaboration to identify randomised trials coupled with the term "trache*" to identify tracheostomies. We identified relevant studies initially by title, then by abstract, and finally by full text. Initially two authors did the electronic searches in duplicate and then repeated them independently. We also searched the 
bibliographies of reports of randomised trials and any identified reviews. Finally we contacted UK experts in the subject.

\section{Study selection and data extraction}

We selected studies for inclusion in the analysis if they were randomised or quasi-randomised clinical trials including adult patients requiring artificial ventilation. The intervention was early tracheostomy, compared with either continued translaryngeal intubation or continued translaryngeal intubation followed by late tracheostomy. The primary outcome measure in the review was mortality; secondary outcomes were length of stay in the critical care unit, duration of artificial ventilation, and incidence of ventilator associated pneumonia. We combined hospital and 30 day mortality in the analysis, and if the point at which mortality was assessed was not given we assumed it to be hospital mortality. Not all studies included all outcome measures.

\section{Statistics and analysis}

We recorded mortality and the presence of hospital acquired pneumonia at any time in the study period as binary variables and length of stay in the critical care unit and duration of artificial ventilation as continuous variables. We used a random effects meta-analysis with RevMan 4.1 software (Cochrane Collaboration, Oxford) to analyse the data. We considered $\mathrm{I}^{2}>50 \%$ to indicate significant heterogeneity between the trials.

\section{Results}

The initial searches identified 15950 unique titles. After initial screening by title and then abstract, we identified 12 randomised clinical trials from manuscript review. We excluded studies without either an English title or abstract. We also identified one study from a published conference abstract. ${ }^{18}$ We did not find any further relevant publications by reviewing the bibliography of the selected studies and review articles.

We then excluded two of the randomised studies because the timing of early and late tracheostomy were separated only by a 24 hour period, ${ }^{19} 20$ another because the timing of the early tracheostomy was after seven days (a criterion of this review), ${ }^{18}$ and a further two because the articles did not contain any data on the outcome measures on which this review is based. ${ }^{51}$ We excluded another study because of clear evidence of bias either in the selection of patients or their exclusion after randomisation, as a 1:1 randomisation schedule resulted in an approximately 5:1 final distribution of patients between study arms. ${ }^{22}$ Finally we excluded another study as it described only the study design ${ }^{23}$ Figure 1 shows the search process.

Overall, only five trials with a combined study population of 406 patients were original, randomised or quasi-randomised, methodologically sound clinical trials of the timing of tracheostomy in the management of artificially ventilated, critically ill adults. These studies spanned a 20 year period between 1984 and 2004. One of the studies compared tracheostomy only with continuing translaryngeal intubation. ${ }^{24}$

Table 1 summarises the study characteristics. The two oldest studies ${ }^{25}$ were quasi-randomised, using randomisation techniques that allowed the assignment of the patient to be determined before enrolment, thereby producing a potential for bias. The studies by Saffle et al and Rumbak et al were appropriately randomised. ${ }^{16}{ }^{17}$ The most recent study was described as randomised but did not define its randomisation strategy. ${ }^{18} 24$

Each of the studies examined different populations of critically ill patients, in critical care units for surgical, trauma, and burns patients and one multicentre study in three medical criti-

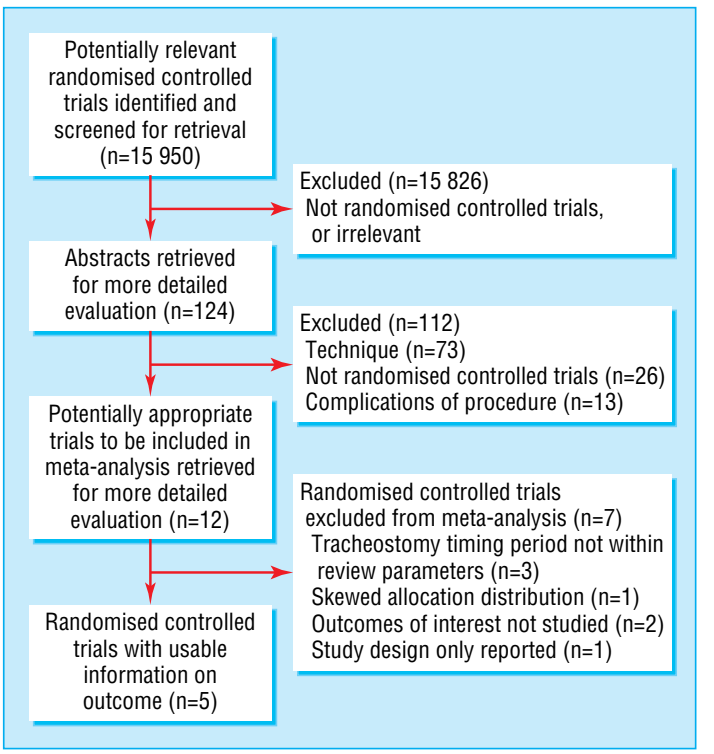

Fig 1 Process of study selection of randomised controlled trials

cal care units. All studies came from the United States, with the exception of the Moroccan study of Bouderka et al.

\section{Mortality}

Information on hospital mortality was available for four of the five studies (332 patients). Figure 2 shows the random effects meta-analysis of relative risk of hospital mortality for early compared with late tracheostomy. The timing of tracheostomy did not alter mortality significantly (relative risk 0.79, 95\% confidence interval 0.45 to $1.39, \mathrm{P}=0.42$ ).

\section{Risk of hospital acquired pneumonia}

Information on the number of patients developing hospital acquired pneumonia while in the intensive care unit was available for all five studies. Figure 3 shows the random effects meta-analysis of relative risk of hospital acquired pneumonia for early versus late tracheostomy. The risk of developing hospital acquired pneumonia was unchanged by tracheostomy timing $(0.90,0.66$ to $1.21, \mathrm{P}=0.48)$.

\section{Duration of artificial ventilation}

Information on the duration of artificial ventilation was available for four of the five studies (332 patients). Figure 4 shows the forest plot. The combined results showed duration of artificial ventilation to be significantly lower in the early tracheostomy group (weighted mean difference -8.5 days, $95 \%$ confidence interval -15.3 days to -1.7 days, $\mathrm{P}=0.03$ ).

\section{Length of stay in the critical care unit}

Information on the length of stay in a critical care unit was available for two of the five studies (226 patients). Figure 5 shows the forest plot. Overall the length of stay in the critical care unit was significantly lower in the early tracheostomy group ( -15.3 days, -24.6 days to -6.1 days, $\mathrm{P}=0.001$ ).

\section{Discussion}

Early tracheostomy placement may lead to a markedly reduced duration of ventilation and shorter stays in critical care units in artificially ventilated, critically ill adult patients. However, the limited numbers of studies and patients available for analysis leave some doubt as to the accuracy of the result. 
Table 1 Summary of studies included in systematic review

\begin{tabular}{|c|c|c|c|c|c|c|c|}
\hline \multirow[b]{2}{*}{ Study } & \multirow{2}{*}{$\begin{array}{c}\text { No of } \\
\text { patients } \\
(\mathrm{n}=406)\end{array}$} & \multicolumn{2}{|c|}{ Timing of tracheostomy } & \multirow[b]{2}{*}{ Intensive care setting } & \multirow[b]{2}{*}{ Randomisation } & \multirow{2}{*}{$\begin{array}{l}\text { Mortality } \\
\text { expressed on } \\
\text { intention to treat } \\
\text { basis }\end{array}$} & \multirow{2}{*}{$\begin{array}{l}\text { Duration of ventilation and } \\
\text { critical care stay expressed } \\
\text { on intention to treat basis }\end{array}$} \\
\hline & & Early & Late & & & & \\
\hline $\begin{array}{l}\text { Bouderka et al } \\
2004^{24}\end{array}$ & 62 & $\begin{array}{l}5-6 \text { days after } \\
\text { admission }\end{array}$ & $\begin{array}{l}\text { Prolonged } \\
\text { endotracheal } \\
\text { intubation }\end{array}$ & $\begin{array}{l}\text { Unit for patients with } \\
\text { head injuries }\end{array}$ & $\begin{array}{l}\text { Randomised; method not } \\
\text { stated }\end{array}$ & Implied & Implied both \\
\hline Dunham et al $1984^{25}$ & 74 & $\begin{array}{l}\text { 3-4 days after initiation } \\
\text { of translaryngeal } \\
\text { intubation }\end{array}$ & $\begin{array}{l}14 \text { days after } \\
\text { initiation of } \\
\text { translaryngeal } \\
\text { intubation }\end{array}$ & Trauma unit & Quasi-randomised & $\begin{array}{l}\text { Mortality not } \\
\text { recorded } \\
\text { Pneumonia } \\
\text { analysed by } \\
\text { intention to treat }\end{array}$ & Yes \\
\hline $\begin{array}{l}\text { Rodriguez et al } \\
1990^{26}\end{array}$ & 106 & $\begin{array}{l}\text { 1-7 days after } \\
\text { admission to intensive } \\
\text { care unit }\end{array}$ & $\begin{array}{l}8 \text { or more days after } \\
\text { admission to } \\
\text { intensive care unit }\end{array}$ & Surgical unit & Quasi-randomised & Implied & Implied both \\
\hline Rumbak et al $2004^{17}$ & 120 & $\begin{array}{l}0-2 \text { days after initiation } \\
\text { of mechanical } \\
\text { ventilation }\end{array}$ & $\begin{array}{l}\text { 14-16 days after } \\
\text { initiation of } \\
\text { mechanical } \\
\text { ventilation }\end{array}$ & Three medical units & True randomisation & Implied & Yes \\
\hline Saffle et al $2002^{16}$ & 44 & $\begin{array}{l}\text { Next available operative } \\
\text { day }\end{array}$ & $\begin{array}{l}14 \text { days after burn } \\
\text { injury }\end{array}$ & Burns unit & True randomisation & Implied & Yes \\
\hline
\end{tabular}

\section{Possible limitations}

It is possible that we did not identify all available published research, but by performing a comprehensive and repeated literature search we minimised this risk. In spite of this extensive searching, we identified only five original, randomised or quasirandomised clinical trials of the timing of tracheostomy in the

\begin{tabular}{|c|c|c|c|c|c|}
\hline Study & $\begin{array}{c}\text { Early } \\
\text { racheostomy } \\
\mathrm{n} / \mathrm{N}\end{array}$ & $\begin{array}{c}\text { Late } \\
\text { tracheostomy } \\
\mathrm{n} / \mathrm{N}\end{array}$ & $\begin{array}{c}\text { Relative risk } \\
\text { (random) } \\
95 \% \mathrm{Cl}\end{array}$ & $\begin{array}{l}\text { Weight } \\
(\%)\end{array}$ & $\begin{array}{c}\text { Relative risk } \\
\text { (random) } \\
95 \% \mathrm{Cl}\end{array}$ \\
\hline Bouderka et al $2004^{24}$ & $2412 / 31$ & $7 / 31$ & & 23.71 & 1.71 (0.78 to 3.77$)$ \\
\hline Rodriguez et al $1990^{26}$ & $269 / 51$ & $13 / 35$ & $\longrightarrow$ & 24.53 & 0.75 (0.35 to 1.60$)$ \\
\hline Rumbak et al $2004^{17}$ & $7 \quad 19 / 60$ & $37 / 60$ & $\rightarrow$ & 35.71 & 0.51 (0.34 to 0.78$)$ \\
\hline Saffle et al $2002^{16}$ & $4 / 21$ & $6 / 23$ & & 16.05 & 0.73 (0.24 to 2.23$)$ \\
\hline Total $(95 \% \mathrm{Cl})$ & 163 & 169 & & 100.00 & 0.79 (0.45 to 1.39 ) \\
\hline$\chi^{2}=7.11, \mathrm{df}=3$ & & & 0.512 & 10 & \\
\hline
\end{tabular}

Fig 2 Random effects meta-analysis of relative risk (95\% confidence interval) of mortality with early compared with late tracheostomy

\begin{tabular}{|c|c|c|c|c|c|}
\hline Study & $\begin{array}{c}\text { Early } \\
\text { racheostomy } \\
\mathrm{n} / \mathrm{N}\end{array}$ & $\begin{array}{c}\text { Late } \\
\text { tracheostomy } \\
\mathrm{n} / \mathrm{N}\end{array}$ & $\begin{array}{c}\text { Relative risk } \\
\text { (random) } \\
95 \% \mathrm{Cl})\end{array}$ & $\begin{array}{c}\text { Weight } \\
(\%)\end{array}$ & $\begin{array}{l}\text { Relative risk } \\
\text { (random) } \\
95 \% \mathrm{Cl})\end{array}$ \\
\hline Bouderka et al $2004^{24}$ & $2418 / 31$ & $19 / 31$ & $\rightarrow$ & 19.18 & 0.95 (0.63 to 1.43 ) \\
\hline Dunham et al $1984^{25}$ & $5 \quad 20 / 34$ & $20 / 40$ & & 18.89 & 1.18 (0.77 to 1.79$)$ \\
\hline Rodriguez et al 199026 & $2640 / 51$ & $53 / 55$ & $=$ & 27.62 & 0.81 (0.70 to 0.95 ) \\
\hline Rumbak et al $2004^{17}$ & 7 $3 / 60$ & $15 / 60$ & & 5.29 & 0.20 (0.06 to 0.66 ) \\
\hline Saffle et al $2002^{16}$ & $21 / 21$ & $22 / 23$ & " & 29.02 & 1.05 (0.96 to 1.14$)$ \\
\hline Total $(95 \% \mathrm{Cl})$ & 197 & 209 & $<$ & 100.00 & 0.90 (0.66 to 1.21$)$ \\
\hline$\chi^{2}=29.58, d f=3$ & & & 0.5112 & 10 & \\
\hline
\end{tabular}

Fig 3 Random effects meta-analysis of relative risk (95\% confidence interval) of hospital acquired pneumonia with early compared with late tracheostomy

\begin{tabular}{|c|c|c|c|c|c|c|c|c|}
\hline \multirow[t]{2}{*}{ Study } & \multicolumn{2}{|c|}{ Early tracheostomy } & \multicolumn{2}{|c|}{ Late tracheostomy } & \multirow{2}{*}{\multicolumn{2}{|c|}{$\begin{array}{c}\text { Weighted mean } \\
\text { difference (random) } \\
95 \% \mathrm{Cl}\end{array}$}} & \multirow{2}{*}{$\begin{array}{l}\text { Weight } \\
(\%)\end{array}$} & \multirow{2}{*}{$\begin{array}{c}\text { Weighted mean } \\
\text { difference (random) } \\
95 \% \mathrm{Cl}\end{array}$} \\
\hline & $\mathbf{N}$ & Mean (SD) & $\mathbf{N}$ & Mean (SD) & & & & \\
\hline Bouderka et al 200424 & 31 & $14.50(7.30)$ & 31 & $17.50(10.60)$ & - & & 28.34 & $-3.00(-7.53$ to 1.53$)$ \\
\hline Rodriguez et al $1990^{26}$ & 51 & $12.00(7.14)$ & 55 & $32.00(22.25)$ & - & & 25.57 & $-20.00(-26.20$ to -13.80$)$ \\
\hline Rumbak et al $2004^{17}$ & 60 & $7.60(4.00)$ & 60 & $17.40(5.30)$ & $=$ & & 31.76 & $-9.80(-11.48$ to -8.12$)$ \\
\hline Saffle et al $2002^{16}$ & 21 & $35.50(20.62)$ & 23 & $31.40(24.94)$ & + & & 14.32 & $4.10(-9.38$ to 17.58$)$ \\
\hline Total $(95 \% \mathrm{Cl})$ & 163 & & 169 & & & & 100.00 & $-8.49(-15.32$ to -1.66$)$ \\
\hline \multirow[t]{2}{*}{$\chi^{2}=22.96, d f=3$} & & & & & $\begin{array}{ll}-50 & 0\end{array}$ & 50 & & \\
\hline & & & & & Favours early & slate & & \\
\hline
\end{tabular}

Fig 4 Random effects meta-analysis of weighted mean difference (95\% confidence interval) of duration of ventilation in days 


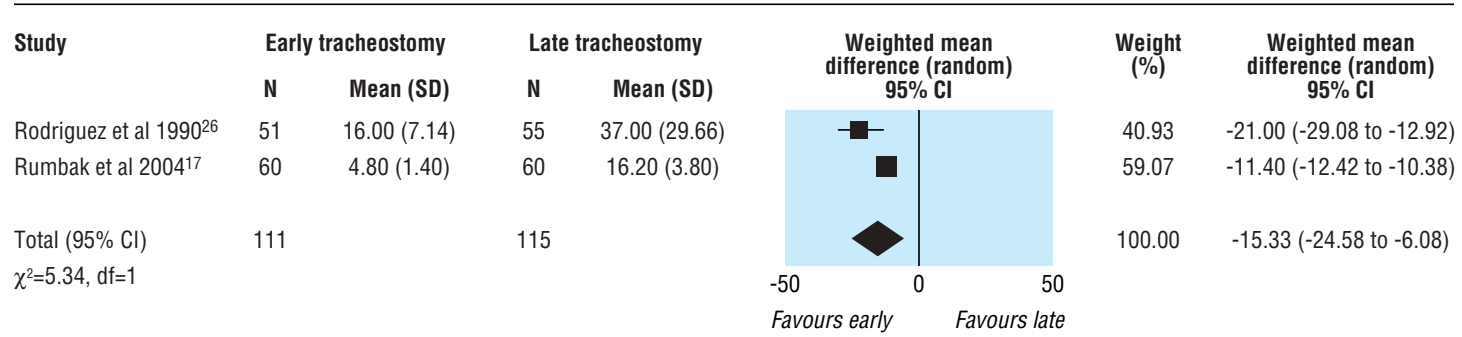

Fig 5 Random effects meta-analysis of weighted mean difference ( $95 \%$ confidence interval) of length of stay in the critical care unit in days

management of artificially ventilated, critically ill adults. The trials all had relatively small study populations, giving a total combined population of only 406 patients.

\section{Heterogeneity between studies}

Heterogeneity between the studies included in this review arises because the exclusion and inclusion criteria differed across the trials and because each trial used a different definition of what constituted an "early" or "late" tracheostomy (table 1). The critical care populations studied also differed because the trials were undertaken in different specialist rather than general critical care units. Some heterogeneity existed in the way some outcomes were defined. The diagnostic criteria for hospital acquired pneumonia varied between studies (table 2), leading to large differences in the proportion of patients reported as developing this complication in the same treatment arm of different studies. The heterogeneity of the studies was also quantified $\left(\mathrm{I}^{2}\right) .{ }^{27}$ All had high $\mathrm{I}^{2}$ values $(57.8 \%, 86.5 \%, 81.3 \%, 86.9 \%)$, showing that most of the variability across the studies is due to heterogeneity rather than chance.

If an early tracheostomy strategy were adopted widely many mechanically ventilated patients could have a tracheostomy placed earlier in their stay, a procedure they would not receive when a more conservative, late approach is used. However, in the randomised controlled trial by Rumbak et al, eight patients (35\% of survivors) in the late tracheostomy arm no longer had a clinical need for a tracheostomy by the time this procedure was indicated by protocol. ${ }^{17}$ Although this review would support a limited benefit-that is, a shorter stay in the intensive care unit and duration of ventilation-premature or ill advised placement of a tracheostomy may not represent an appropriate balance of risk. To avoid this problem, attempts have been made to develop formulas to predict the probability of a patient requiring prolonged ventilation, ${ }^{28}$ allowing better selection of patients likely to benefit

\begin{tabular}{|c|c|}
\hline Study & Diagnosis of pneumonia \\
\hline Bouderka et $\mathrm{al}^{24}$ & Criteria not stated \\
\hline Dunham et $\mathrm{al}^{25}$ & $\begin{array}{l}\text { Respiratory infections confirmed and documented } \\
\text { by the hospital infectious disease service, using } \\
\text { rigorous criteria }\end{array}$ \\
\hline Rodriguez et a $\left.\right|^{26}$ & $\begin{array}{l}\text { Required all five of the following: temperature } \\
>38.6^{\circ} \mathrm{C} \text {, white blood cell count }>15 \times 10^{9} / \mathrm{l} \\
\text { inflammatory cells and bacteria on Gram stain, } \\
\text { positive sputum culture, and new infiltrate on } \\
\text { chest } x \text { ray film }\end{array}$ \\
\hline Rumbak et al ${ }^{17}$ & $\begin{array}{l}\text { Confirmed by bronchoscopy using } \\
\text { semi-quantitative cultures from protected } \\
\text { specimen brushes }\left(>1000 \text { organisms } / \mathrm{ml}^{-1}\right) \text { or } \\
\text { broncho-alveolar lavage }\left(>10000 \text { organisms } / \mathrm{ml}^{-1}\right) \\
\text { or a positive Gram stain }\end{array}$ \\
\hline Saffle et al ${ }^{16}$ & $\begin{array}{l}\text { CDC standard criteria for intubated patients } \\
\text { (Garner JS, Jarvis WR, Emori TG, Horan TC, } \\
\text { Hughes JM. CDC definitions for nosocomial } \\
\text { infections. Am J Infect Control 1988;16:128-40) }\end{array}$ \\
\hline
\end{tabular}

CDC=US Centers for Disease Control and Prevention from early tracheostomy. However, to date no validated specific and sensitive test or scoring system is available that predicts the need for prolonged ventilation in general populations in critical care, and so the selection of patients for tracheostomy remains a subjective decision.

\section{Conclusion}

Current practice for definitive airway management in critically ill adults uses translaryngeal intubation in the early stages. Tracheostomy is subsequently performed if the attending doctor estimates that the patient will require an extended period of artificial ventilation. However, if the results from our meta-analysis can be generalised, in spite of the small numbers of trials and patients, it may be advisable to place a tracheostomy earlier on in the proceedings. The UK critical care community has recently highlighted this specific clinical question in a priority setting exercise. The first, large scale study in UK intensive care units of the effect of the timing of tracheostomy powered on mortality has now started recruitment.

Contributors: JDY, LM and VSB selected studies, extracted and analysed data, and with JG wrote the paper. JDY is guarantor.

Funding: None.

Competing interests: JDY and LM are involved in TracMan, a randomised controlled trial in UK intensive care units for adults, which compares the effect of the timing of tracheostomy, funded by the Intensive Care Society. Ethical approval: Not required.

1 Heffner JE. Timing of tracheotomy in mechanically ventilated patients. Am Rev Respir Dis 1993; 147:768-71

2 Pelosi P, Severgnini P. Tracheostomy must be individualized! Crit Care 2004;8:322-4.

3 Byhahn C, Wilke HJ, Lischke V, Westphal K. Translaryngeal tracheostomy: two modified techniques versus the basic technique--early experience in 75 critically ill adults. Intens Care Med 2000;26:457-61.

4 Qureshi AI, Suarez JI, Parekh PD, Bhardwaj A. Prediction and timing of tracheostomy in patients with infratentorial lesions requiring mechanical ventilatory support. Crit in patients with infraten

5 Stauffer JL, Olson DE, Petty TL. Complications and consequences of endotracheal intubation and tracheotomy. A prospective study of 150 critically ill adult patients. Am JMed 1981;70:65-76.

\section{What is already known on this topic}

Tracheostomy is considered to be the standard care in patients requiring long term ventilation

Many trials have reported the use of tracheostomy in adult patients, but most involved small numbers of participants with specific conditions

Previous reviews have reached different conclusions about the timing of tracheostomy in adult patients

\section{What this study adds}

Earlier placement of a tracheostomy in critically ill patients may shorten duration of artificial ventilation and length of stay in intensive care 
6 Skaggs JA, Cogbill CL. Tracheostomy: management, mortality, complications. Am Surg 1969;35:393-6.

7 Shlugman D, Satya-Krishna R, Loh L. Acute fatal haemorrhage during percutaneous dilatational tracheostomy. BrJ Anaesth 2003;90:517-20.

8 Ryan DW, Kilner AJ. Another death after percutaneous dilational tracheostomy. $\mathrm{Br} \mathrm{J}$ Anaesth 2003;91:925-6.

9 Freeman BD, Isabella K, Lin N, Buchman TG. A meta-analysis of prospective trials comparing percutaneous and surgical tracheostomy in critically ill patients. Chest 2000;118:1412-8

10 Graham JS, Mulloy RH, Sutherland FR, Rose S. Percutaneous versus open tracheostomy: a retrospective cohort outcome study. J Trauma 1996;41:245-8.

11 Boynton JH, Hawkins K, Eastridge BJ, O'Keefe GE. Tracheostomy timing and the duration of weaning in patients with acute respiratory failure. Crit Care 2004;8:R261-7.

12 Plummer AL, Gracey DR. Consensus conference on artificial airways in patients receiving mechanical ventilation. Chest 1989;96:178-80.

13 Fischler L, Erhart S, Kleger GR, Frutiger A. Prevalence of tracheostomy in ICU patients. A nation-wide survey in Switzerland. Intens Care Med 2000;26:1428-33.

14 Kane TD, Rodriguez JL, Luchette FA. Early versus late tracheostomy in the trauma patient. Respir Care Clin NAm 1997;3:1-20.

15 Maziak DE, Meade MO, Todd TR. The timing of tracheotomy: a systematic review. Chest 1998;114:605-9.

16 Saffle JR, Morris SE, Edelman L. Early tracheostomy does not improve outcome in burn patients.J Burn Care Rehabil 2002;23:431-8

17 Rumbak MJ, Newton M, Truncale T, Schwartz SW, Adams JW, Hazard PB. A prospective, randomized study comparing early percutaneous dilatational tracheostomy to prolonged translaryngeal intubation (delayed tracheostomy) in critically ill medical patients. Crit Care Med 2004;32:1689-94

18 Barquist E. A randomized prospective study of early vs late tracheostomy in trauma patients. Proceeding of the American Association for the Surgery of Trauma, 2004 www.aast.org/PDF/04absOral.pdf (accessed 10 May 2005).

19 Cheng DC, Karski J, Peniston C, Raveendran G, Asokumar B, Carroll J, et al. Early tracheal extubation after coronary artery bypass graft surgery reduces costs and improves resource use. A prospective, randomized, controlled trial. Anesthesiology 1996;85:1300
20 Quasha AL, Loeber N, Feeley TW, Ullyot DJ, Roizen MF. Postoperative respiratory care: a controlled trial of early and late extubation following coronary-artery bypass grafting. Anesthesiology 1980;52:135-41.

21 El-Naggar M, Sadagopan S, Levine H, Kantor H, Collins VJ. Factors influencing choice between tracheostomy and prolonged translaryngeal intubation in acute respiratory failure: a prospective study. Anesth Analg 1976;55:195-201.

22 Sugerman HJ, Wolfe L, Pasquale MD, Rogers FB, O’Malley KF, Knudson M, et al. Multicenter, randomized, prospective trial of early tracheostomy. J Trauma 1997:43:741-7.

23 Blot F. [A study of early tracheostomy in patients undergoing prolonged mechanical ventilation]. Rev Mal Respir 2003;20:411-20. (In French.)

24 Bouderka MA, Fakhir B, Bouaggad A, Hmamouchi B, Hamoudi D, Harti A. Early tracheostomy versus prolonged endotracheal intubation in severe head injury. J Trauma cheostomy versu

25 Dunham CM, LaMonica C. Prolonged tracheal intubation in the trauma patient. $J$ Trauma 1984;24:120-4.

26 Rodriguez JL, Steinberg SM, Luchetti FA, Gibbons KJ, Taheri PA, Flint LM. Early tracheostomy for primary airway management in the surgical critical care setting. Surgery 1990;108:655-9.

27 Higgins JPT, Thompson SG, Deeks JJ, Altman DG. Measuring inconsistency in meta-analyses. $B M J$ 2003;327:557-60.

28 Sellers BJ, Davis BL, Larkin PW, Morris SE, Saffle JR. Early prediction of prolonged ventilator dependence in thermally injured patients. J Trauma 1997;43:899-903. (Accepted 19 April 2005)

doi 10.1136/bmj.38467.485671.E0

Adult Intensive Care Unit, John Radcliffe Hospital, Oxford OX3 9DU John Griffiths specialist registrar

J Duncan Young comsultant

Nuffield Department of Anaesthetics, University of Oxford, John Radcliffe Hospital

Vicki S Barber trial coordinator

Lesley Morgan trial coordinator

Correspondence to:J Duncan Young duncan.young@nda.ox.ac.uk 